\title{
GROWTH STRAINS AND RELATED WOOD STRUCTURES IN THE LEANING TRUNKS AND BRANCHES OF TROCHODENDRON ARALIOIDES - A VESSEL-LESS DICOTYLEDON
}

\author{
Ling-Long Kuo-Huang ${ }^{1}$, Shin-Shin Chen ${ }^{2}$, Yan-San Huang ${ }^{2}$, \\ Shiang-Jiuun Chen ${ }^{1} \&$ Yi-In Hsieh ${ }^{1}$
}

\begin{abstract}
SUMMARY
Leaning trunks and branches of Trochodendron aralioides Sieb. \& Zucc., a primitive vessel-less dicotyledon, show increased radial growth and gelatinous fibers on the upper side similar to the features found in dicotyledons with vessels. The patterns of peripheral longitudinal growth strain are variable among trees but similar at different heights within the same leaning trunk. Growth strains on the lower side of the trunks are very small but they are relatively large on the lower side of the branches. Growth stress in the branches is partly affected by the gravitational bending stress, which would be exerted mostly on the lower side. Large spring back strains of branches are associated with large surface strains. Both the microfibril angle (MFA) and the percentage area of gelatinous fiber show positive relationships with the measured strains. The MFA of the $\mathrm{S}_{2}$ wall layer in tracheids in the opposite wood is $24.6 \pm 2.2^{\circ}$, whereas the MFA of gelatinous layer in the tension wood is only $14.2 \pm 2.7^{\circ}$. The difference of MFA between the gelatinous fibers and the opposite wood is one of the factors accounting for the large contracting force for reorientation.
\end{abstract}

Key words: Trochodendron aralioides, gelatinous fiber, microfibril angle, surface growth strain, vessel-less angiosperm.

\section{INTRODUCTION}

Secondary growth in coniferous and dicotyledonous trees is formed as a result of vascular cambial activity generating xylem cells inward and phloem cells outward. During the formation of secondary cell wall in the wood, growth stress accumulates (Boyd 1972; Yamamoto et al. 1991; Guitard et al. 1999) and sometimes simultaneously heterogeneous growth stress occurs on the periphery of stems. Growth stress tends to keep the leaning trunks and branches at an equilibrium position. Increased growth stresses are found at specific locations on the periphery of leaning trunks and the branches and

1) Department of Life Science, Institute of Ecology and Evolutionary Biology, University of Taiwan, Taipei, Taiwan.

2) Division of Forest Utilization, Taiwan Forestry Research Institute, Taipei, Taiwan.

*) Corresponding author [E-mail: linglong@ntu.edu.tw].

Associate Editor: Barbara Lachenbruch 
are associated with the formation of reaction woods where eccentric stem swelling occurs (Watanabe 1967). Using a simulation of a mechanical model, Yamamoto et al. (2002) concluded that the growth stress generated in the reaction wood is sufficient to counteract gravitational self-loading of branches. The formation of reaction wood accompanied with the increased growth stresses enables the leaning trunk to exhibit the observed growth reorientation.

In conifers, compression wood is formed on the lower side of a leaning trunk where there is strong compressive stress (Timell 1986). There are different levels of severity of compression wood, and a typical compression wood has high specific gravity, higher lignin and galactan contents, and lower cellulose content than normal wood. The tracheids of severe compression wood are shorter than normal wood, their cross sections are usually round with intercellular space, and the $S_{3}$ layer is missing. The $S_{2}$ cell wall of compression wood may have helical checking with large microfibril angle (MFA) (Boyd 1980).

Angiosperms usually form tension wood on the upper side of leaning trunks or branches where strong tensile stress exists (Panshin et al. 1964; Okuyama et al. 1986, 1994). In the species with gelatinous fibers (i.e. Prunus, Robinia, Acer, Quercus, Sassafras), large longitudinal tensile stresses appear in the region where the crosssectional area of gelatinous layers are large (Okuyama et al. 1994). In species that lack gelatinous fibers (i.e. Magnolia and Liriodendron), higher cellulose content, lower lignin content, and smaller MFA are observed in the tension wood than the normal wood (Okuyama et al. 1994). Like compression wood, there are different severities of tension wood with various values of MFA, cellulose/lignin ratio, G-layer thickness, and growth stress.

Höster and Liese (1966) reported that, whether they are gymnosperms or not, trees and shrubs with a xylem consisting mostly of axial tracheids tend to develop compression wood. Some species of the primitive dicotyledons are vessel-less and the axial tracheids are the main component of the xylem. The reaction wood of some primitive dicotyledons, such as Drimys and Pseudowintera, is mostly compression wood-like (Kučera \& Philipson 1977, 1978; Timell 1986). The only significant anatomical characteristics of the so-called compression wood of Pseudowintera colorata is the large microfibril angle (Meylan 1981). It is possible that these vessel-less dicotyledons reorient themselves by producing cells with high MFA without developing a typical compression wood or tension wood cell. In Magnolia, no gelatinous fibers are found (Okuyama et al. 1994), but there are large tensile stresses in the regions with small MFAs. Okuyama et al. (1994) suggested that the high tensile longitudinal growth stress is mainly due to the tensile stresses of the cellulose microfibrils that run in the axial direction.

Trochodendron aralioides Sieb. \& Zucc., the only species of the genus and of the family Trochodendraceae (Smith 1945; Cronquist 1981), is a primitive, vessel-less tree. Although the xylem contains no vessels, Jorgensen et al. (1974) reported that the phloem is the angiosperm type. In Taiwan, T. aralioides grows up to $10 \mathrm{~m}$ high and commonly is found on the slope of foggy mountain areas (Chaw 1992). In contrast to Drimys and Pseudowintera, the reaction wood of leaning trunks and branches of Trochodendron occurs on the upper (adaxial) side, which is similar to that found in angiosperms 
with vessels. In this study, we examined the anatomy and the peripheral distribution of released growth strains of leaning trunks and branches of $T$. aralioides. We then discussed the relationships between anatomical structures of tension wood and growth strains of the leaning trunks and branches in this species.

\section{MATERIALS AND METHODS}

\section{Plant materials}

Inclined trunks and branches from six 25-30-year-old trees of Trochodendron aralioides were studied. Two leaning trees (A and B) were selected from Yingzihling $\left(121^{\circ}\right.$ $19^{\prime} \mathrm{E}, 24^{\circ} 54^{\prime} \mathrm{N}, 942 \mathrm{~m}$ above sea level), and four trees (C-F) were from Chilanshan station $\left(121^{\circ} 15^{\prime}-121^{\circ} 30^{\prime} \mathrm{E}, 24^{\circ} 15^{\prime}-24^{\circ} 45^{\prime} \mathrm{N}, 1100 \mathrm{~m}\right.$ above sea level), Forest Conservation Institute, Taiwan. The diameter at breast height (DBH) of trees A, B, C, D, $\mathrm{E}$ and $\mathrm{F}$ were $14,16.5,7.5,11,9$, and $11 \mathrm{~cm}$, respectively.

\section{Growth stress measurements}

The trunk of Trochodendron aralioides is usually dichotomously branched at various heights. In tree A the first dichotomous branching was at $3 \mathrm{~m}$ above ground but tree $\mathrm{B}$ was already dichotomously branched at about $1 \mathrm{~m}$ (Fig. 1a,b). Measurements of the peripheral distributions of surface growth strains on the inclined trunks were made on the standing trees around the circumference (at $45^{\circ}$ intervals) at $65 \mathrm{~cm}$ above ground for tree A. In tree B, measurements were made at both 35 and $62 \mathrm{~cm}$ above ground (Fig. 1a,b) to learn the effect of dichotomous branching. Given orderly distributed pattern of the peripheral stresses in the first two trees, the measurements for trees C and D were made only at the upper, lateral, and lower positions at about $60 \mathrm{~cm}$ above ground. The lower side of the trunk was designated as $0^{\circ}$, and the upper side as $180^{\circ}$. Immediately after removing the bark at the specified positions, electrical resistance strain gauges were glued with cyanoacrylate adhesive to the xylem in the longitudinal direction. A portable digital strain meter (Model UCAM-1A Kyowa Ltd., Tokyo, Japan) with a 40-channel scanner (USB-11A) was used for measurement. After calibrating the strain gauges to zero, the surface growth strain was released by the kerf method (Sasaki et al. 1978), i.e., grooves 1-1.5 cm deep were made in the xylem around the strain gauge with a handsaw as well as a chain saw and the released strain was determined when the readings stabilized. The tested areas were cut into blocks for microscopical studies.

In order to have suitable branch locations for measurements on the standing trees, we selected one branch from tree $\mathrm{E}$ and two branches from tree $\mathrm{F}$ to measure the spring back strains and the longitudinal surface growth strains at different distances from the trunk (see Table 2). The measurements were made on standing trees. After removing the bark, strain gauges were glued in the longitudinal direction at the upper side and the lower side of the marked positions of the branches. After gauges were zeroed, the branch was cut off and its spring back strain due to the self-loading determined. Thereafter, the longitudinal surface growth strains were measured by cross-cutting the branch at a position $5 \mathrm{~mm}$ in front or behind the strain gauge. 


\section{Anatomical and structural study}

A segment from each of the tested areas was collected for microstructural studies. Cross-sectional and tangential sections $(0.5 \times 1 \mathrm{~cm})$ were prepared for microscopic examination. The relative amounts of the lignified wall, gelatinous wall, and lumen of the cells were measured on $0.015 \mathrm{~mm}^{2}$ area from 50 cross sections for each segment. The microfibril angle (MFA) in the reaction and the opposite wood zones was determined on 25-35 $\mu \mathrm{m}$ thick tangential sections cut from the latewood of the outermost two rings of each wood block for which we had measured strain. The sections were stained with $2 \%$ iodine solution for $1 \mathrm{~min}$. and observed after rinsing with $60 \%$ nitric acid (Huang et al. 1997). The MFAs were measured in 50 gelatinous fibers or the lignified tracheids at each point.

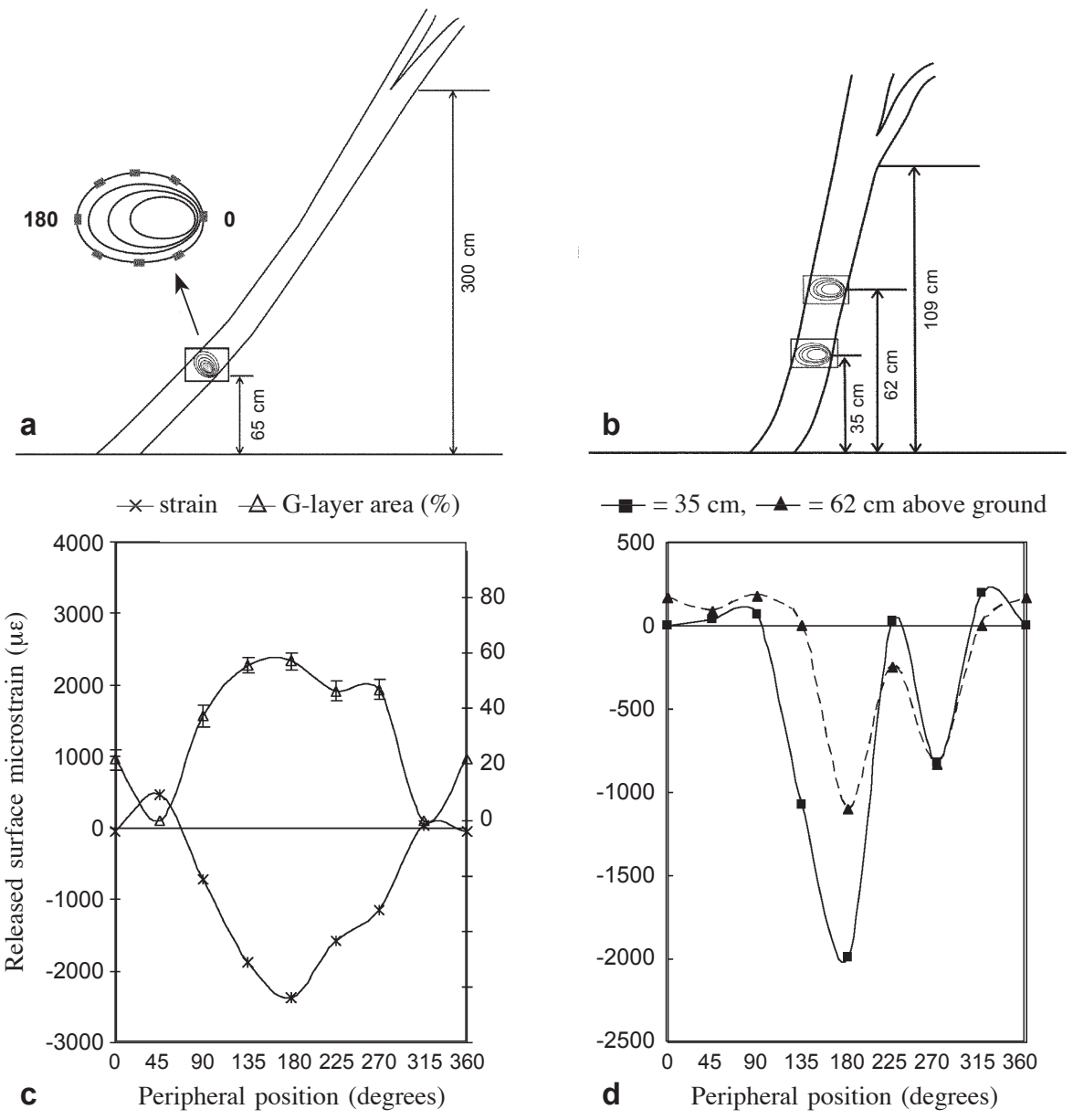

Figure 1. Measurements of released surface growth strains around the periphery of $\mathbf{a}$ : the trunk of tree A at $65 \mathrm{~cm}$ height and $\mathbf{b}$ : tree B at heights of 35 and $62 \mathrm{~cm}$. c: Peripheral distribution of surface growth strains and G-layer area (\%) in tree A. d: Peripheral distribution of surface growth strains at two heights in tree B. 
Table 1. Tree number and the averages of growth strains, microfibril angles $(n=50)$ and cell wall area percentages $(n=50)$ at different positions of the leaning trunks.

\begin{tabular}{|c|c|c|c|c|c|c|c|c|c|}
\hline \multirow{3}{*}{ 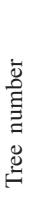 } & \multicolumn{3}{|c|}{ Growth strain $(\mu \mathrm{m})$} & \multicolumn{3}{|c|}{ Cell wall area $(\%)$} & \multicolumn{3}{|c|}{$\operatorname{MFA}\left({ }^{\circ}\right)$} \\
\hline & \multirow[b]{2}{*}{ Upper } & \multirow[b]{2}{*}{ Side } & \multirow[b]{2}{*}{ Lower } & \multicolumn{2}{|c|}{$\begin{array}{l}\text { G-fiber in } \\
\text { tension wood }\end{array}$} & \multirow{2}{*}{$\begin{array}{c}\text { Tracheid in } \\
\text { opposite } \\
\text { wood }\end{array}$} & \multicolumn{2}{|c|}{$\begin{array}{l}\text { G-fiber in } \\
\text { tension wood }\end{array}$} & \multirow{2}{*}{$\begin{array}{c}\begin{array}{c}\text { Tracheid } \\
\text { opposite } \\
\text { wood }\end{array} \\
\mathrm{S}_{2} \text {-layer }\end{array}$} \\
\hline & & & & G-layer & $\mathrm{S}_{2}$-layer & & G-layer & $\mathrm{S}_{2}$-layer & \\
\hline $\mathbf{A}$ & -2383 & -933 & -59 & $\begin{array}{l}57.2 \\
(3.1)\end{array}$ & $\begin{array}{l}13.6 \\
(3.1)\end{array}$ & $\begin{array}{l}56.7 \\
(2.4)\end{array}$ & $\begin{array}{r}9.4 \\
(1.9)\end{array}$ & $\begin{array}{r}14.0 \\
(2.2)\end{array}$ & $\begin{array}{l}24.0 \\
(2.6)\end{array}$ \\
\hline $\mathbf{B}_{1}$ & -1989 & -827 & 191 & $\begin{array}{l}56.5 \\
(2.7)\end{array}$ & $\begin{array}{r}11.2 \\
(3.1)\end{array}$ & $\begin{array}{l}55.6 \\
(2.0)\end{array}$ & $\begin{array}{r}11.4 \\
(1.7)\end{array}$ & $\begin{array}{l}23.8 \\
(2.5)\end{array}$ & $\begin{array}{r}29.0 \\
(2.5)\end{array}$ \\
\hline $\mathbf{B}_{2}$ & -1100 & -831 & 166 & $\begin{array}{l}57.7 \\
(2.4)\end{array}$ & $\begin{array}{r}12.3 \\
(2.6)\end{array}$ & $\begin{array}{l}57.1 \\
(1.8)\end{array}$ & $\begin{array}{l}11.3 \\
(2.4)\end{array}$ & $\begin{array}{c}18.4 \\
(2.4)\end{array}$ & $\begin{array}{l}25.8 \\
(2.6)\end{array}$ \\
\hline C & -1866 & -211 & -57 & $\begin{array}{l}67.4 \\
(3.4)\end{array}$ & $\begin{array}{l}15.1 \\
(2.9)\end{array}$ & $\begin{array}{l}52.2 \\
(2.1)\end{array}$ & $\begin{array}{l}15.9 \\
(2.2)\end{array}$ & $\begin{array}{l}24.5 \\
(2.6)\end{array}$ & $\begin{array}{l}27.2 \\
(2.3)\end{array}$ \\
\hline D & -863 & -389 & -60 & $\begin{array}{l}58.7 \\
(3.4)\end{array}$ & $\begin{array}{r}9.8 \\
(2.6)\end{array}$ & $\begin{array}{l}56.0 \\
(2.1)\end{array}$ & $\begin{array}{l}10.9 \\
(2.2)\end{array}$ & $\begin{array}{l}14.2 \\
(2.6)\end{array}$ & $\begin{array}{l}17.9 \\
(2.5)\end{array}$ \\
\hline
\end{tabular}

$\mathrm{B}_{1}$ : at trunk height of $35 \mathrm{~cm} ; \mathrm{B}_{2}$ : at trunk height of $62 \mathrm{~cm}$.

MFA: average of microfibril angle.

Number in brackets is standard deviation.

\section{RESULTS AND DISCUSSION}

\section{Peripheral longitudinal growth strain of the leaning trunks}

Large negative released growth strains in the longitudinal direction were detected on the upper side $\left(180^{\circ}\right)$ of the inclined trunks of trees A-D (Table 1, Fig. 1c, d), indicating these trees had large tensile stresses like most angiosperms when they are leaning. Normally tensile stress is found on the periphery of the erect trunks of both gymnosperms and angiosperms and the compressive stress occurs almost exclusively in the compression woods of the inclined trunks of gymnosperms (Huang et al. 1998, 2005). However, a small compressive strain was found on the lower side of the leaning trunk of the vessel-less Trochodendron aralioides.

\section{Growth strains of the branches}

Observation of branch cross sections showed that the pith was more eccentric in samples closest to the trunk (Table 2). The symmetry of the cross section may also be affected significantly by the direction of the winds. The increased adaxial radial growth of the tension wood is similar to that found in most hardwoods.

Spring back strains were contractile on the upper side, and extensive on the lower side of branches (Table 2). High contraction surface strains $(-1453 \mu \varepsilon \pm 343 \mu \varepsilon$ ) existed longitudinally on the upper side of branches; however, high extension surface strain $(1975 \mu \varepsilon \pm 646 \mu \varepsilon)$ existed longitudinally on the lower side of branches. Note that the average magnitude of the spring back strain on the lower side of the branch is about 
$65 \%$ larger than the surface strain. There is also a positive relationship between the growth strain and the spring back strain. The relationships are stronger for the lower side $\left(\mathrm{R}^{2}=0.83\right)$ than for the upper side $\left(\mathrm{R}^{2}=0.53\right)$ of the branch (Fig. 2$)$.

Yoshida et al. (1992a, b, 1999) reported that the relationships between growth stresses and physical properties were different in branches than in stems. They suggested that in addition to the growth stress, other factors such as the response to weeping (self-loading in axes that aren not close to vertical) contributes to the strains of branches. In this study, we observed a greater growth strain on the lower sides of the branch than in the

Table 2. Tree and branch number, growth strains, spring back strains, microfibril angles $(n=50)$ and cell wall area percentages $(n=50)$ at different distances from the trunk.

\begin{tabular}{|c|c|c|c|c|c|c|c|c|c|c|c|c|c|}
\hline \multirow{3}{*}{ 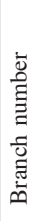 } & \multirow{3}{*}{$\begin{array}{c}\mathrm{L} \\
(\mathrm{cm})\end{array}$} & \multirow{3}{*}{$\begin{array}{l}\mathrm{R}_{1} \\
(\mathrm{~cm})\end{array}$} & \multirow{3}{*}{$\begin{array}{c}\mathrm{R}_{2} \\
(\mathrm{~cm})\end{array}$} & \multirow{2}{*}{\multicolumn{2}{|c|}{$\begin{array}{r}\text { Spring back } \\
\text { strain }(\mu \mathrm{m})\end{array}$}} & \multirow{2}{*}{\multicolumn{2}{|c|}{$\begin{array}{l}\text { Surface growth } \\
\text { strain }(\mu \mathrm{m})\end{array}$}} & \multicolumn{3}{|c|}{ Cell wall area $(\%)$} & \multicolumn{3}{|c|}{$\operatorname{MFA}\left({ }^{\circ}\right)$} \\
\hline & & & & & & & & \multicolumn{2}{|c|}{$\begin{array}{l}\text { G-fiber in } \\
\text { tension wood } \\
\text { opposite }\end{array}$} & \multirow{2}{*}{\begin{tabular}{|c}
$\begin{array}{c}\text { Tracheid } \\
\text { in } \\
\text { opposite } \\
\text { wood }\end{array}$ \\
$\mathrm{S}_{2}$-layer
\end{tabular}} & \multicolumn{2}{|c|}{$\begin{array}{l}\text { G-fiber in } \\
\text { tension wood } \\
\text { opposite }\end{array}$} & \multirow{2}{*}{ 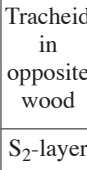 } \\
\hline & & & & Upper & Lower & Upper & Lower & G-layer & $\mathrm{S}_{2}$-layer & & G-layer & $\mathrm{S}_{2}$-layer & \\
\hline \multirow{3}{*}{$\mathbf{E}$} & 16.5 & 2.1 & 1.2 & -1455 & 1748 & -1562 & 977 & $\begin{array}{l}57.4 \\
(2.8)\end{array}$ & $\begin{array}{l}13.7 \\
(2.4)\end{array}$ & $\begin{array}{l}56.0 \\
(1.9)\end{array}$ & $\begin{array}{l}13.1 \\
(2.4)\end{array}$ & $\begin{array}{l}20.1 \\
(1.7)\end{array}$ & $\begin{array}{l}24.1 \\
(2.7)\end{array}$ \\
\hline & 32.0 & 1.8 & 1.2 & -1391 & 1868 & -2185 & 882 & $\begin{array}{l}67.8 \\
(2.2)\end{array}$ & $\begin{array}{l}13.8 \\
(2.3)\end{array}$ & $\begin{array}{l}58.3 \\
(2.7)\end{array}$ & $\begin{array}{l}12.0 \\
(1.9)\end{array}$ & $\begin{array}{l}17.7 \\
(1.8)\end{array}$ & $\begin{array}{l}24.1 \\
(2.7)\end{array}$ \\
\hline & 61.0 & 1.5 & 1.2 & -1134 & 1327 & -1500 & 225 & $\begin{array}{l}70.4 \\
(3.0)\end{array}$ & $\begin{array}{l}14.1 \\
(2.2)\end{array}$ & $\begin{array}{l}59.0 \\
(2.1)\end{array}$ & $\begin{array}{l}12.9 \\
(2.4)\end{array}$ & $\begin{array}{l}19.1 \\
(2.1)\end{array}$ & $\begin{array}{l}25.3 \\
(2.2)\end{array}$ \\
\hline \multirow{4}{*}{$\mathbf{F}_{1}$} & 16.5 & 2.8 & 1.2 & -518 & 1074 & -976 & -83 & $\begin{array}{l}70.8 \\
(2.8)\end{array}$ & $\begin{array}{l}13.8 \\
(2.8)\end{array}$ & $\begin{array}{l}59.8 \\
(1.9)\end{array}$ & $\begin{array}{l}11.8 \\
(2.2)\end{array}$ & $\begin{array}{l}18.2 \\
(1.9)\end{array}$ & $\begin{array}{l}21.7 \\
(2.2)\end{array}$ \\
\hline & 45.0 & 1.7 & 1.2 & -1611 & 914 & -1821 & 537 & $\begin{array}{l}67.6 \\
(2.7)\end{array}$ & $\begin{array}{l}21.9 \\
(3.1)\end{array}$ & $\begin{array}{l}57.0 \\
(2.1)\end{array}$ & $\begin{array}{l}11.6 \\
(1.6)\end{array}$ & $\begin{array}{l}18.0 \\
(1.8)\end{array}$ & $\begin{array}{l}24.6 \\
(2.8)\end{array}$ \\
\hline & 79.5 & 1.4 & 1.2 & -923 & 2187 & -1003 & 469 & $\begin{array}{l}72.8 \\
(2.9)\end{array}$ & $\begin{array}{l}19.8 \\
(2.9)\end{array}$ & $\begin{array}{l}58.8 \\
(3.0)\end{array}$ & $\begin{array}{l}11.7 \\
(2.2)\end{array}$ & $\begin{array}{l}18.1 \\
(1.9)\end{array}$ & $\begin{array}{l}22.5 \\
(2.4)\end{array}$ \\
\hline & 106.5 & 1.2 & 1.1 & -1411 & 1366 & -1962 & 320 & $\begin{array}{l}69.3 \\
(2.4)\end{array}$ & $\begin{array}{l}21.1 \\
(2.7)\end{array}$ & $\begin{array}{l}60.0 \\
(2.6)\end{array}$ & $\begin{array}{l}11.0 \\
(1.8)\end{array}$ & $\begin{array}{l}17.8 \\
(2.1)\end{array}$ & $\begin{array}{l}25.3 \\
(2.7)\end{array}$ \\
\hline \multirow{4}{*}{$\mathbf{F}_{2}$} & 23.4 & 0.9 & 0.8 & -1802 & 2459 & -1953 & 1813 & $\begin{array}{l}64.2 \\
(2.8)\end{array}$ & $\begin{array}{l}17.1 \\
(2.9)\end{array}$ & $\begin{array}{l}63.1 \\
(3.0)\end{array}$ & $\begin{array}{l}10.6 \\
(2.2)\end{array}$ & $\begin{array}{l}18.0 \\
(1.8)\end{array}$ & $\begin{array}{l}22.2 \\
(2.5)\end{array}$ \\
\hline & 46.1 & 0.7 & 0.7 & -1991 & 3633 & -1843 & 3102 & $\begin{array}{l}66.1 \\
(2.7)\end{array}$ & $\begin{array}{l}17.3 \\
(3.1)\end{array}$ & $\begin{array}{l}63.2 \\
(2.4)\end{array}$ & $\begin{array}{l}10.6 \\
(2.3)\end{array}$ & $\begin{array}{l}18.1 \\
(2.0)\end{array}$ & $\begin{array}{l}25.2 \\
(2.7)\end{array}$ \\
\hline & 56.4 & 0.7 & 0.7 & -2008 & 2674 & -1836 & 2397 & $\begin{array}{l}66.8 \\
(2.9)\end{array}$ & $\begin{array}{l}15.9 \\
(3.0)\end{array}$ & $\begin{array}{l}61.6 \\
(2.8)\end{array}$ & $\begin{array}{l}11.0 \\
(1.7)\end{array}$ & $\begin{array}{l}17.9 \\
(2.1)\end{array}$ & $\begin{array}{l}24.6 \\
(2.7)\end{array}$ \\
\hline & 79.4 & 0.6 & 0.6 & -1736 & 2474 & -1536 & 2329 & $\begin{array}{l}73.1 \\
(2.8)\end{array}$ & $\begin{array}{l}15.4 \\
(3.1)\end{array}$ & $\begin{array}{l}54.8 \\
(3.0)\end{array}$ & $\begin{array}{l}11.1 \\
(1.9)\end{array}$ & $\begin{array}{l}18.4 \\
(2.2)\end{array}$ & $\begin{array}{l}22.0 \\
(2.6)\end{array}$ \\
\hline
\end{tabular}

L: Distance from trunk.

$\mathrm{R}_{1}$ :Distance from the cambium to the pith on the upper side of a cross section.

$\mathrm{R}_{2}$ :Distance from the cambium to the pith on the lower side of a cross section.

Number in brackets is standard deviation. 

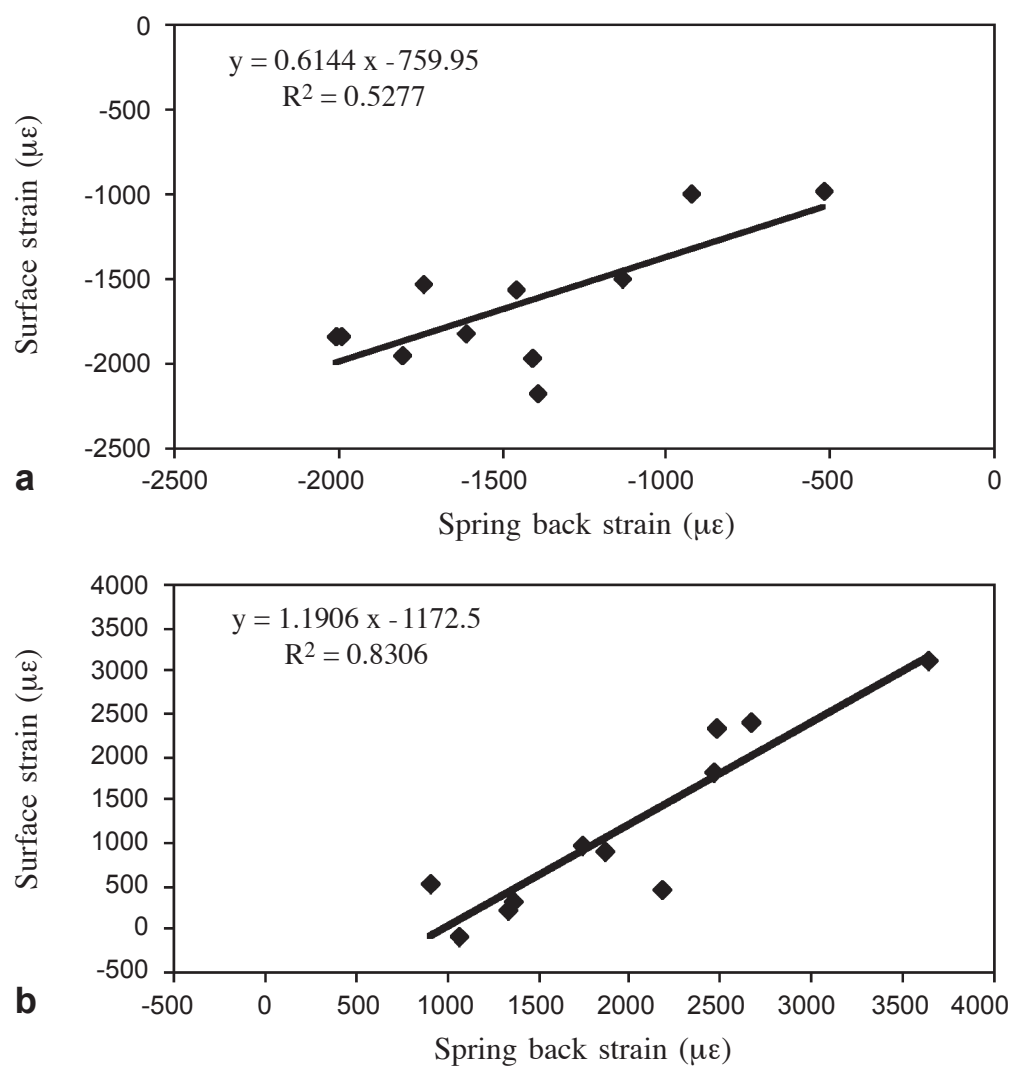

Figure 2. Relationships between spring back and surface strains of $\mathbf{a}$ upper side and $\mathbf{b}$ lower side of the branches.

trunk of $T$. aralioides. The average spring back strain on the lower side of branches is about $65 \%$ larger than that of the surface strain. This may suggest that generation of growth stress in the branches is partly affected by the gravitational bending stress due to self-loading, which may be exerted mostly on the lower side of the branch.

\section{Wood structures in relation to surface growth strains}

The current study confirmed the observation of Onaka (1949) that the vessel-less angiosperm Trochodendron has tension wood and G-fibers. Figures $3 \mathrm{a}$ and $3 \mathrm{c}$ show the gelatinous fibers in the tension wood and figures $3 \mathrm{~b}$ and $3 \mathrm{~d}$ show the tracheids in the opposite wood of T. aralioides. Similar to the findings of Onaka (1949), the gelatinous fiber of Trochodendron had thick gelatinous layers in place of most of the $\mathrm{S}_{2}$-layer of the normal tracheid.

The upper sides of both inclined trunks and branches contained tension wood tissue with gelatinous fibers and displayed high contractive strains. This result agrees with the study of Washusen and Waugh (2003) that the growth strain was found to be a good indicator of the presence of gelatinous fibers in wood tissue taken from the immediate 

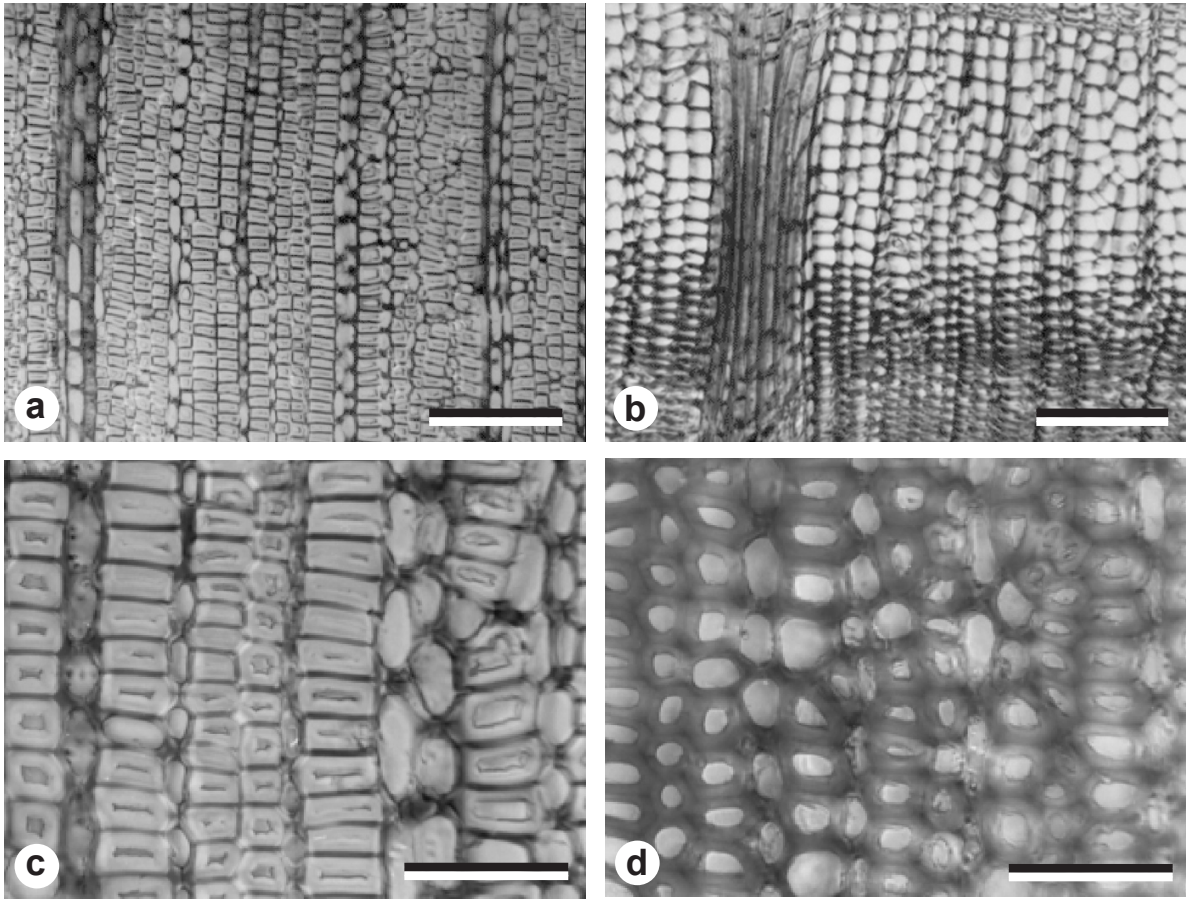

Figure 3. Cross-section images of $\mathbf{a}$ and $\mathbf{c}$ gelatinous fibers in the tension wood and $\mathbf{b}$ and $\mathbf{d}$ tracheids in the opposite wood. - Scale bars in a \& $\mathrm{b}=100 \mu \mathrm{m}$, in $\mathrm{c} \& \mathrm{~d}=40 \mu \mathrm{m}$.

position where growth strain was measured (Fig. 1c). We also found that the patterns of peripheral longitudinal growth strain are variable among trees (Fig. 1c versus 1d) but very similar at different heights along the segment of a leaning trunk (Fig.1d). Gelatinous fibers can be found within old vertical trunks, but such reaction wood is associated with internal stresses or the residual stress from previous reorientation of axis displacement (Trénard \& Guéneau 1975). In gymnosperms, compression wood occurs on the lower sides of the leaning trunks and branches which show large positive strain values. Although the lower side of branch-wood of T. aralioides exhibits high extension strains (positive values), no typical compression wood was found. It is well known that the gelatinous layer of tension wood fibers contributes to the mechanical function of the dicotyledonous trees (Archer 1986; Clair et al. 2003).

There was a positive relationship between the percentage of G-layer and the absolute values of the contractive strain in the trunk of tree A (Fig. 1c). Figures $4 \mathrm{a}$ and $4 \mathrm{~b}$ compare the measured surface strains of gelatinous fibers in tension wood and non-gelatinous fibers in opposite wood of the trunk and branches. There was a higher percentage of gelatinous layer and lower cell lumen area in the tension wood of branches than trunks (Fig. 5). Opposite wood was very similar in terms of cell composition in branches and trunks, and had a much higher cell lumen area than the tension wood (Fig. 5). 

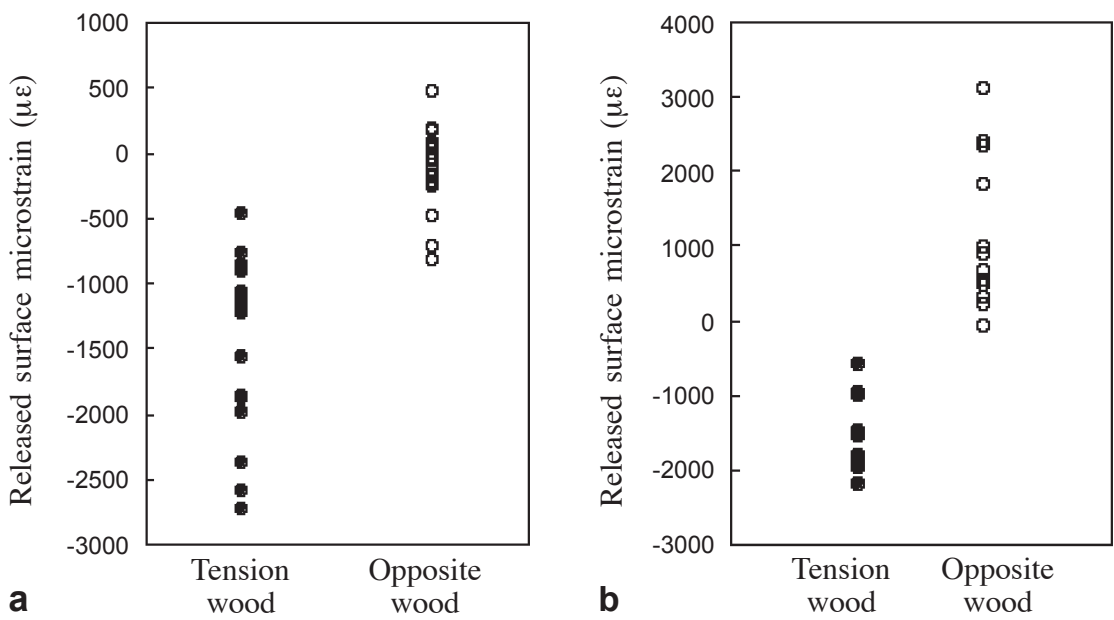

Figure 4. Measured surface strains of gelatinous fibers in the tension wood and tracheids in the opposite wood of $\mathbf{a}$ the trunks and $\mathbf{b}$ the branches.

In both gymnosperms and arboreal dicotyledons, stress is considered to arise from the cellulosic component of the wood according to the cellulose tension hypothesis (Bamber 2001). It is suggested that in dicotyledons the cellulose microfibrils are laid down as stretched and extended, longitudinally oriented springs and thus exert a tensile force tending to right or stabilize the tree. The low values of lignin/cellulose ratio

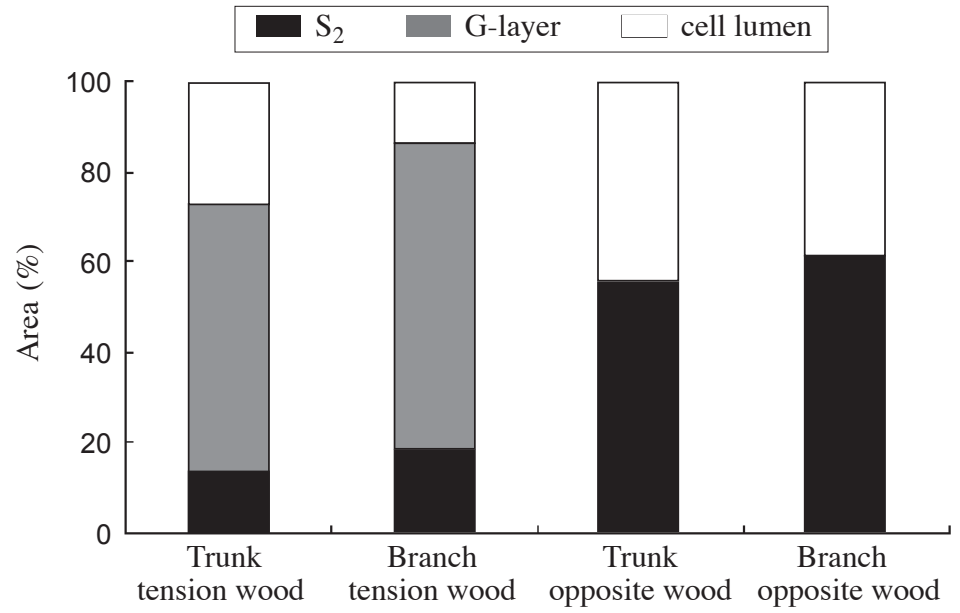

Figure 5. Averages of the area percentages of lignified wall, gelatinous wall, and lumen of the cells in the cross sections from trunks and branches. 
and MFA often reported from tension wood and especially from gelatinous fibers are thought to facilitate the contraction of microfibrils, thus maximizing longitudinal tensile stress. There is a close relationship between growth stress and MFA (Okuyama et al. 1994, 1986; Yamamoto et al. 1995). Okuyama et al. (1994) suggested that microfibril angle is the important factor in the generation of force in tension wood. Based on the unified hypothesis, Guitard et al. (1999) applied the mechanical model to discuss the relationship between the growth strain and MFA. They calculated the critical MFA at which the longitudinal growth stress changed from tensile to compressive at about 20 30 ${ }^{\circ}$. In Chamaecyparis, the MFAs have a transition angle at 20 25 (Yamamoto et al. 1991; Huang et al. 2005).

The large difference between the gelatinous fibers and the non-gelatinous fibers is one of the main factors that account for the large contractile force. Based on the difference in MFA, the contribution of the non-gelatinous fibers in the tension wood zone to the tensile stress may be small. Figure 6 shows the relationship between the MFA and the released longitudinal growth strain on the surface of the trunks and branches. All the MFAs of the gelatinous layer of G-fibers were below $20^{\circ}$ and significantly smaller than the MFAs of the $\mathrm{S}_{2}$-layer of the tracheids in opposite wood. The positive trends between MFA and the released surface strain can be seen, and the change from tension to compression stress at $20^{\circ} \mathrm{MFA}$ is clearer for the data collected from the branches.

As described in this paper and in other studies, reaction wood in angiosperms is more diverse than in gymnosperms. The processes of re-orientating the trunk and branches involve the generation of growth stresses which may or may not trigger the formation of tension wood in a vessel-less angiosperm. Necesaný and Oberländerová (1967) suggested that the wood of homoxylous species, such as most of the gymnosperms, has

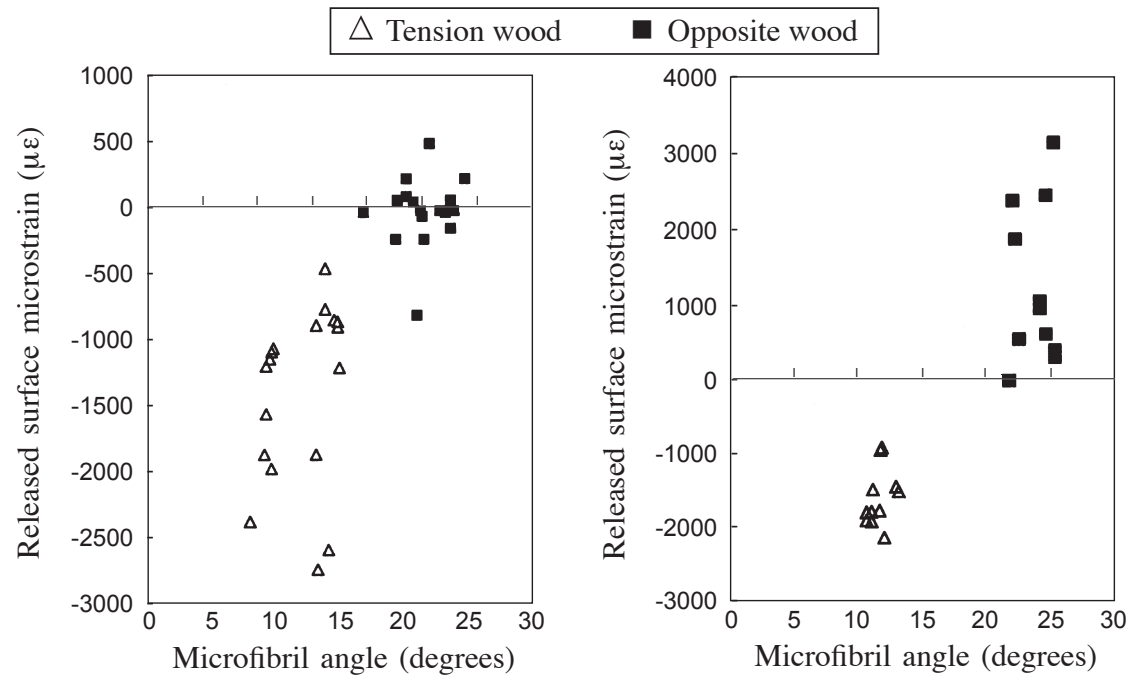

Figure 6. Microfibril angle and the measured surface strains on the tension and opposite wood sides of $\mathbf{a}$ the trunks and $\mathbf{b}$ the branches. 
growth promotion in the abaxial part of leaning axes. This suggestion proved to be valid in the vessel-less dicotyledonous trees of Pseudowintera colorata which form wood with a high MFA wood on the lower side and lack typical tension wood on the upper side (Meylan 1981). Such features are consistent with Pseudowintera's taxonomic position as one of the most primitive angiosperms (Kučera \& Philipson 1978). However, the results presented here and the finding of Onaka (1949) that tension wood is formed on the upper side of a stem and branches of Trochodendron suggest that, unlike Drimys and Pseudowintera, Trochodendron may belong phylogenetically to the advanced group of angiosperms, the basal eudicotyledons (APG 2003). In addition to growth strain and wood anatomy reported in this paper, it would be interesting to investigate other aspects of the nature of reaction wood formation such as wood chemistry and the complex interactions between growth regulators and environment factors of vessel-less angiosperms.

\section{ACKNOWLEDGEMENTS}

The authors would like to thank Yingzihling and Chilanshan stations of the Forest Conservation Institute for assisting with the sample collection. Thanks are also due to Dr. Chih-Lin Huang for critical reading and valuable comments. This study was funded by the research project (NSC-92-2313-B-002-045) of the National Science Council of Taiwan.

\section{REFERENCES}

APG. 2003. An update of the angiosperm phylogeny group classification for the orders and families of flowering plants: APG II. Bot. J. Linn. Soc. 141: 399-436.

Archer, R.R. 1986. Growth stresses and strains in trees. Springer-Verlag, New York. pp. 203204.

Bamber, R.K. 2001. A general theory for the origin of growth stresses in reaction wood: How trees stay upright. IAWA J. 22: 205-212.

Boyd, J.D. 1972. Tree growth stresses V. Evidence of an origin in differentiation and lignification. Wood Sci. Technol. 6: 251-162.

Boyd, J.D. 1980. Relationship between fibre morphology, growth strain and physical properties of wood. Aust. For. Res. 10: 337-360.

Chaw, S.M. 1992. Phytogeography and Botanical inventory of Taiwan. In: C.I. Peng (ed.), Institute of Botany, Academia Sinica Monograph Series No. 12: 63-77. Taipei, Taiwan.

Clair, B., J. Ruelle \& B. Thibaut. 2003. Relationship between growth stress, mechanical-physical properties and proportion of fibre with gelatinous layer in Chestnut (Castanea sativa Mill.). Holzforschung 57: 189-195.

Cronquist, A. 1981. An integrated system of classification of flowering plants. Columbia University Press, New York.

Guitard, D., H. Masse, H. Yamamoto \& T. Okuyama. 1999. Growth stress generation: a new mechanical model of dimensional change of wood cells during maturation. J. Wood Sci. 45: 384-391.

Höster, H.L. \& W. Liese. 1966. Über das Vorkommen von Reaktionsgewebe in Wurzeln und Ästen der Dikotyledonen. Holzforschung 20: 80-90.

Huang, C.L., N.P. Kutscha, G.J. Leaf \& R.A. Megraw. 1997. Comparison of microfibril angle measurement techniques. In: B.G. Butterfield (ed.), Microfibril angle in wood: 177-205. University of Canterbury, New Zealand. 
Huang, Y.S., S.S. Chen, L.L. Kuo-Huang \& C.M. Lee. 2005. Growth strain in the trunk and branches of Chamaecyparis formosensis and its influence on tree form. Tree Physiol. 25: $1119-1126$.

Jorgensen, L.B., J.D. Moller \& P. Wagner. 1974. Secondary phloem of Trochodendron aralioides. Bot. Tidsskr. 69: 217-238.

Kučera, L.J. \& W.R. Philipson. 1977. Growth eccentricity and reaction anatomy in branchwood of Drymis winteri and five native New Zealand trees. New Zealand J. Bot. 15: 517-524.

Kučera, L.J. \& W.R. Philipson. 1978. Growth eccentricity and reaction anatomy in branchwood of Pseudowintera colorata. Amer. J. Bot. 65: 601-607.

Meylan, B.A. 1981. Reaction wood in Pseudowintera colorata a vessel-less dicotyledon.Wood Sci. Technol. 15: 81-92.

Necesaný, V. \& A. Oberländerová. 1967. The analysis of causes of different formation of reaction wood in gymnosperms and angiosperms. Drev. Vvsk. 12: 61-71.

Okuyama, T., A. Kawai, Y. Kikata \& H. Yamamoto. 1986. The growth stresses in reaction wood. In Proc. 18th IUFRO World Congress, Yugoslavia, Div. 5, For. Proc.: 249-260.

Okuyama, T., H. Yamamoto, M. Yoshida, Y. Hattori \& R.R. Archer. 1994. Growth stresses in tension wood: role of microfibrils and lignification. Ann. Sci. For. 51: 291-300.

Onaka, F. 1949. Studies on compression- and tension-wood. Mokuzai Kenkyo,Wood Res. Inst. Kyoto Univ. 1, 88 pp.

Panshin, A.J., C. DeZeeuw \& H.P. Brown. 1964. Textbook of wood technology: 257-276. McGraw-Hill Book Co., New York.

Sasaki, Y., T. Okuyama \& Y. Kikata. 1978. The evolution process of the growth stress in the tree: the surface stress on the tree. Mokuzai Gakkaishi 24: 149-157.

Smith, A.C. 1945. A taxonomic review of Trochodendron and Tetracentron. J. Arnold Arbor. 26: $121-142$.

Timell, T.E. 1986. Compression wood in gymnosperms. Vol. 1: 63-89. Springer-Verlag, New York.

Trénard, Y. \& P. Guéneau. 1975. Relations entre contraintes de croissance longitudinales et bois de tension dans le hêtre (Fagus sylvatica L.). Holzforschung 29 : 217-223.

Washusen, R. \& J.I.G. Waugh. 2003. The relationship between longitudinal growth strain and the occurrence of gelatinous fibers in 10- and 11-year-old Eucalyptus globulus Labill. Holz Roh- Werkstoff 61: 299-303.

Watanabe, H. 1967. A study of the origin of longitudinal growth stress in tree stems. Bull. Kyushu Univ. For. 41: 169-176.

Yamamoto, H., T. Okuyama \& M. Yoshida. 1995. Generation process of growth stresses in cell walls - Analysis of growth stress generation by using a cell model having three layer $\left(\mathrm{S}_{1}\right.$, $\mathrm{S}_{2}$, and 1+P). Mokuzai Gakkaishi 41: 1-8.

Yamamoto, H., T. Okuyama., M. Yoshida \& K. Sugiyama. 1991. Generation process of growth stresses in cell walls. Growth stress in compression wood. Mokuzai Gakkaishi 37: 94 100.

Yamamoto, H., M. Yoshida \& T. Okuyama. 2002. Growth stress controls negative gravitropism in wood plant stems. Planta 216: 280-292.

Yoshida, M., T. Nakamura., H. Yamamoto \& T. Okuyama. 1999. Negative gravitropism and growth stress in GA3-treated branches of Prunus spachiana Kitamura f. spachiana cv. Plenarosea. J. Wood Sci. 45: 368-372.

Yoshida, M., T. Okuyama \& H. Yamamoto. 1992a. Tree forms and internal stresses. III. Growth stresses of branches. Mokuzai Gakkaishi 38: 663-668.

Yoshida, M., T. Okuyama., H. Yamamoto \& K. Sugiyama. 1992b. Tree forms and internal stresses - Stresses around the base of branches. Mokuzai Gakkaishi 38: 657-662. 